\title{
Effective Staff Relationships as An Impetus for Growth in 21st Century Church
}

\author{
${ }^{1}$ Simon A. Ishola, Ph.D. $\quad{ }^{2}$ Francis O. Oladipo \\ 1. Lecturer, Faculty of Education, Nigerian Baptist Theological Seminary, Ogbomoso, Nigeria \\ 2.Ph.D. Candidate, Nigerian Baptist Theological Seminary, Ogbomoso, Nigeria
}

\begin{abstract}
Effective staff relationships is a stimulus to church developmental growth in all facets of church life. It is expedient that each church and religious organizations should imbibe because of its benefits that cannot be overemphasized. This paper considers the necessity of staff relationships for growth in the $21^{\text {st }}$ Century church by exploring into the biblical perspective of staff relationships. The necessity of staff relationships was also consider, such as it enhances mutual encouragement both personal and spiritual; it facilitates and improve the workforce; it promotes growth in all facets; teamwork, delegation and supervision are enhanced; it is problemsolving; it is enjoyable and broaden staff understanding, and building a Christlike attitude and relationships are not exempted. The possible challenges in staff relationships were also considered, such as staining, denting and destroying each other reputation and integrity. Mistrust and lack of sincere commitment among staff members. Inattentive to staff voices, preferential treatment and rivalry. Lack of recognition, motivation and appreciation of staff. The unconducive atmosphere and lack of openness and the spirit of cooperation. Excessive use of power and social stratification; and unforgiving spirit. The paper concludes that staff relationships are inevitable in contemporary churches and religious organizations. Healthy staff relationships should be built and encouraged for efficiency, growth, productivity and fulfilment of the primary purpose of multi-staff both between the volunteer staff members, non-ministerial staff and ministerial staff.
\end{abstract}

Keywords: Effective, Staff Relationships, Impetus, Growth

DOI: $10.7176 / \mathrm{JPCR} / 48-02$

Publication date:March $31^{\text {st }} 2020$

\section{Introduction}

Staff relationships is a necessity in $21^{\text {st }}$ Century church, especially in this generation where impersonal generation is encouraged that everyone suffers from feeling that a person or an individual is just another number. God is a God of relationship, and he desires a harmonious relationship from those he created in his image. Omotosho (2009: 63-64) asserts that God is three in one, and the three relate in such a cordial relationship that there had never been a misunderstanding or disharmony between them. He further asserts that God wants man also replicate him by sharing such a peaceful relationship or harmonious co-existence relationships with one another. Barlow (2004: 175) asserts that staff relationships should be an exemplary Christian relationship. That is, pastors and staff members must build the kind of interpersonal relationship that can serve as examples of what Christ desires relationally within a church family and between believers and others. Dale (2008: 73) asserts that interpersonal relationships provide the bridges over which ministry moves.

Every church has a staff. Caldwell (2008: 277) defines church staff "as a group of Christian persons called by God who willingly agree with God, a local congregation, and one another to live and out their vocational calling as they guide a church in its mission." Therefore, the strong desire of all churches in the area of staff relationships should be encouraged for effectiveness and growth in all facets of the church ministry. In essence, relationships between church staff are necessary for both human and spiritual. The primary and ultimate concern of churches should be on how to develop and maintained a harmonious relationship of both ministerial staff members, non-ministerial paid staff and the volunteer staff members. Good ministerial leadership is a prerequisite and a conducive atmosphere to promote staff relationship, primarily where multi-staff ministry is practiced. Dale (2008: 73) also asserts that working with volunteers in congregations demands keen relational and managerial skill. God created humanity to be uniquely relational. In essence, men and women were created to be in continuing relationships with God and each other (Hayford, 2013: 211). That is vertical and horizontal relationships.

Relationships can either be primary (expressive ties) or secondary (instrumental ties) relationship (Adeniran and Nihinlola, 2011: 94). Marshall (1991: 135) opines that relationships are a corporate responsibility. The leadership desire of creating a conducive atmosphere in building effective staff relationships cannot be overemphasized. The workability of staff relationships depends on the staff possessing unquestioned loyalty with each other and the church, diligence and hard work for the assigned work (Hyles, 2013: 272). He further asserts that public appreciation for the staff encourages them to be more active and more productive in their work. The spirit of patriotism should always be exhibited by staff members in their various responsibilities. Self-interest, tribalism, sentiments, undue rivalry, bitterness, and pride should be avoided in staff relationships. Given this, this 
presentation will consider the following: the biblical perspectives of staff relationships, the necessity of staff relationships, the challenges of staff relationships and the conclusion.

\section{The Biblical Perspective of Staff Relationships}

There are biblical principles that apply to various kind of relationships that should hold between God and man, man and God and between each other such as husband and wife and staff relationships. The Bible admonished the principle of mutual submission and accountability between the staff members and the church (Anderson, 1985: 109). Examples of staff relationship in the Bible include Abraham with his 318 trained men (Genesis 14: 1-16); Jacob and Laban (Genesis 29: 15-29); Moses and Jethro (Exodus 2: 21-22; 3: 1); Moses, Aaron, Hur and Joshua (Exodus 17: 10); John Baptist with his disciples (Matthew 9: 14); Jesus Christ with his disciples called Apostles (Matthew 10: 2-4) Jesus Christ in his earthly ministry, he established the priority of a relational ministry from the beginning and he was continually taking the first steps to initiate a relationship even among his disciples in John 3: 22 (Spader and Mayes, 1991: 68). They further assert that Jesus's effort to build relationships with people was such a prominent pattern in his life that his enemies tried to use it to discredit him (Matthew 9: 11; Luke 15: 18).

\section{The Necessity of Staff Relationships}

The importance of staff relationships cannot be overemphasized. Anderson (1999: 133) asserts that a growing cadre of employers are hearing their employees refuse job transfers and promotions because it will be too disruptive to personal and family relationships. Adeniran and Nihinlola (2011: 91) asserts that "the way we behave is determined in large measure by our relations with one another." They further assert that "Human life stays incurably relational because the orbits of life are controlled by our relationships." The characteristics of relationships are that people cannot meet regularly in the same general areas without having a relationship. Also, the relationship is that one cannot consistently work with or near people or communicate with them frequently without having working relationships with them.

Also, another characteristic of a relationship is that each relationship is different (Adeniran and Nihinlola, 2011: 94-95). Therefore, the effectiveness and fulfilment of the kingdom assignment of churches depend on how staff members were able to learn and build one-to-one friendships. Staff commitment is a necessity in experiencing pleasant, harmonious and develop staff relationships. Adetunji (2010: 234) asserts that staff members should understand that whatever gift they are using comes from God for the edification of the church and God's glory, not for self-promotion. More so, Dale (2008: 80-81) submits that the following principles contribute to excellent and harmonious staff relationships: Church staffers are people; recognizing that there are different kinds of relationships on church staff; competent staff blend specialist and generalist roles. The more significant the staff, the higher the likelihood there is of relational tension, adopting a healthy management style with staffers, taking a developmental stance, providing forms for communication and mutual nurture. Howard Hendricks (Spader and Mayes, 1991: 67) assert that "You can impress people at a distance; you can only impact them up close. The general principle is this, the closer the personal relationship, the greater the potential impact." Staff relationships keep each staff under the discipline of others (Prime, 2009: 191).

One, it enhances both spiritual and personal basis for mutual encouragement (Prime, 2009: 192). Praying together, sharing personal and family needs and openness through adequate communication, and the exhibition of confidentiality will always safeguard the perils of professionalism among staff members.

Two, it facilitates staff ministerial and church work. Barrow (2004: 175) asserts that good Christian relationships between pastor and staff members facilitate and improve their work and the work of the church.

Three, staff relationships promote growth among staff members and the church. People grow in relationships. Sustainable growth is achieved in staff members' relationships. The Bible admonishes that "Spur one another on toward love and good deeds" (Hebrews 10: 24). Spader and Mayes (1991: 76) asserts that God understands the impact one person can have upon another. Proverbs 27: 17 buttress that "As iron sharpens iron, so one man sharpens another." Without relationships, there can be no sharpening. The more staff members get involved in relationships through contacting and relationship building determines the depth of the church growth and productivity.

Four, it helps in building teamwork, and thereby, independence becomes interdependence. Teamwork through staff relationships is needed within the staff members in the church, especially when two or more people must work together and depend on one another. Dale (2008: 77) submits that team-building model through staff relationships help staff members get acquainted, divide responsibilities, build group cohesion, heighten morale, increase creativity, and deepen loyalty.

Five, it helps in problem-solving through the participation of staff members. Staff relationships allow the use of collective creativity and collective managerial skill through staff participation in problem-solving.

Six, it helps and promotes staff delegation. Staff relationships help in discovering and engaging potential and skilful staff members for church ministries. Through delegation, staff members learn by doing and soften the 
workload, and it also creates room for participatory and shared responsibility between staff members (Dale, 2008: 81). A rough rule of thumb states that "the smaller the church, the greater the importance of relationships; the larger the church, the greater the importance of performance" (Anderson, 1999: 143).

Seven, it enhances supervision among staff members. Through staff relationships, supervision is made possible and comfortable through supportive, structure, mentor-novice, and reciprocal relationship. In staff relationships, supervision blends learning by example, practice, and feedback (Dale, 2008: 82).

Eight, it helps in dealing with difficult staff through the acceptance of difficult staff without approving their attempts to control, building and maintaining an open and up-to-date relationship, anticipating their behavior patterns, working behind the scenes and the use of Christian love with firmness as an antidote for controlling behavior (Dale, 2008: 83-84).

Nine, it helps in enjoying God's work. When staff members through cordial and harmonious relationship solemnly and joyfully enter into a relationship with one another, the outcome is a better relationship and a clearer understanding of how they can most effectively work together and enjoy the Lord's work (Caldwell, 2008: 282). Also, the quality of the relationship between staff members is significantly strengthened.

Ten, it broadens individual staff member understanding. Each person's understanding is widened by having a good understanding of oneself and others in the areas of value system, self-image, the goal, nature, and work of staff ministry; area of responsibilities; church expectations of staff members; leadership style; church's personnel policies and procedure; and discipline that follow suit of every act of indiscipline (Caldwell, 2008: 282).

Eleven, staff relationships help in building Christ-like character among staff members. It is a significant part of a nurturing environment. It encourages and enhances mentorship (Noyce, 1988: 146). Spader and Mayes (1991: 87) asserts that a healthy staff relationship is directly connected to staff effectiveness in helping themselves grow as disciples of Christ. Olson (2014: 106) also asserts that through staff relationships, staff will best develop spirituality and strategy in the company of others. Anderson (1999: 133) also asserts that good character comes from living in communities such as family, neighbourhood, and a religious and civic institution where virtue is encouraged and rewarded. In essence, the best channel to develop virtue and good is through community relationships.

\section{Challenges in Staff Relationships}

Spader and Mayes (1991: 73) opines that in a relationship where there is trust, there can be a vulnerability. It is believed that there should be an in-built biblical principle of relationships holding between staff members, but sometimes it is not. Staff members' relationships should be fraternal, honest, and professional not mindful of the status, but it is not due to the following challenge.

One, staining and destroying each other reputation which is unethical. Staff gossiping, no doubt arises out of staff member feelings of insecurity (Anderson, 1985: 116). Frequently, an insecure person tries to enhance his reputation by tainting the reputations of the person others.

Two, the challenge of mistrust is also militating against staff members' relationship. Spader and Mayes (1991: 67) asserts that the impact of mistrust in staff relationships encourage fear, misconception and makes transparency among the staff members difficult.

Three, lack of staff commitments can inhibit staff relationships. Caldwell (2008: 278) submits that if staff members lack clear and define commitments and expectations with one another and the church, then significant misunderstanding, conflicts, chaos and conflict are inevitable.

Four, inability to listen to both the spoken and unspoken messages such as their observations, grievances, complains, hurts, pains and their need also affects their relationship (Nash, 2013: 246). In essence, the lack of proper communication impedes staff relationship.

Five, self-interest, tribalism, sentiments, undue rivalry, bitterness, and pride among staff are vices that impede staff relationships.

Six, lack of recognition, motivation and appreciation is also a hindrance to staff relationships and staff performance. William James (Beasley-Murray 2005: 46) asserts that "the deepest principle in human nature is the craving to be appreciated; we all need appreciation; we all need encouragement." Barlow (2004: 176) opines that staff members who often labour behind the scenes are hardly noticed, while pastors are noticed and appreciated, especially when churches achieve growth in membership and ministries. He further asserts that pastors who feel threatened by or are jealous of, the giftedness of staff members may take personal credit for the work and accomplishments of staff, leaving staff members feeling unappreciated and perhaps angry. Such a climate and attitude does not build a good staff relationship. Sometimes, staff members see pastors as being interested only in themselves and their career path and these negative mar relationships.

Seven, the unconducive climate is also a hindrance in staff relationships. Barlow (2004: 175-176) submits that the climate of the church is a set of conditions that affect how pastors and staff members communicate, make decisions, feel motivated, handle conflict, work as a team, and show concerns for each other. The right kind of climate can contribute to good staff relationships by facilitating communication between pastors and staff 
members, as well as within the staff. If the climate is conducive, it empowers decision making, nurtures the best efforts, smoothes out problems and disagreements, fosters a team spirit, and develops loyalty and love. However, where the climate is unconducive, all those benefits will be lacking.

Eight, lack of openness, transparency and trust are barriers to staff relationships. The absence of openness keeps the staff members away uninformed of vital information, loosed receptive to their ideas and suggestions, difficult in soliciting for their evaluation feedback and these encourage the staff members to do the same to themselves and the church or pastor (Barlow, 2004: 176). Such actions will always lead to resentment and hurt. Also, distrust is inevitable in the area of integrity and reliability of each other. Self-centered and un-Christlike behaviour can cause a lack of trust and can even damage relationships between pastors and staff members or among the staff. A pastor can foster trust when staff members observe and experience honesty in pastor-staff interpersonal interactions, causing staff members to develop confidence and closeness with the pastor (Barlow, 2004: 176).

Nine, lack of cooperative spirit among the staff members is always tantamount to staff relationships. Barlow (2004: 177) submits that Christian cooperation involves more than actions; it also includes attitudes. He further asserts that sometimes, staff members carried out their responsibilities and tasks in an uncooperative spirit toward the pastor or other staff.

Ten, the inordinate use of power is a challenge to staff relationships. Adeniran and Nihinlola (2011: 100) submits that the struggle for power and the misuse of power constitutes a significant relationship problem.

Eleven, social stratification is also an obstacle to staff relationships. When people are ranked in the workplace into higher or lower positions, the hierarchy of respect and prestige results among staff members. The idea and the syndrome of a boss to the subordinate, seniority to the junior staff (seniority mentality) do mar staff relationships. Lack of giving honour and due respect to whom is due is dangerous to staff relationships. Adeniran and Nihinlola (2011: 100) opines that "A role is a set of behaviours associated with a position a person holds at a certain time. As such, individuals relate to the roles they play and are socialized in the way of interacting with others in their roles. Additionally, status relates to a person's position in a hierarchy. It is the standing or ranking of a person in the hierarchy of a group structure."

Twelve, failing to forgive or seek forgiveness among staff members, dishonour Christ and divides relationships. Inability to show through Christian humility that people are prone to mistake and wrongs and that people and relationship are more important than winning an argument or placing blame makes staff relationships difficult.

For all these aforementioned, Staff members must endeavour to build relationships not only for personal gain but also for mutual benefits. Therefore, to build a Christ-like staff relationship for church growth, two factors are of prime importance in good staff relationships. Those factors are climate and cooperation (Barlow, 2004: 175). The pastor must take responsibility for establishing the right kind of climate for building good staff relationships. He must continually oversee the state of the relationships amongst the staff members, and staff members with the congregation (Marshall, 1991: 131). Likewise, staff members must take responsibility for establishing good relationships with the pastor through cooperation. Staff must also cooperate well with each other. The voice of the staff members, whether spoken or unspoken messages, should be carefully considered, and not to be neglected for Christ-like relationship. The fundamental values for the development of staff relationships are selflessness, self-denial, and sacrifice. For staff relationships not to be truncated and marred, there must be a high level of trust, a high degree of love without compromise, genuine respect or honour must not be neglected, and there must be right understanding or knowledge by the staff members of all that is known and called relationships.

\section{Conclusion}

Staff relationships in contemporary church are inevitable. The biblical principle of staff relationships should always be esteemed in churches and among staff members. In staff relationships, the unknown becomes known. Real perceptions are fleshed out, and bad press is laid to rest in the light of personal integrity and authenticity among staff members. Staff members experience growth in all dimension in the context of relationships. Ministry and fulfilment come to life in a relationship. More so, these concepts of staff relationship must be profoundly understood by staff members and churches in this $21^{\text {st }}$ century, these include: relationship building is a mandatory activity; it is a continuity activity; it is to be done with God, with the church, and with other staff members; and it involves shared responsibility and shared authority. Sincere commitments and clarify expectations among all parties is a prerequisite to healthy staff relationship. The church should be able to provide at least a document that will be a guiding principle with a familiar and standard agreement for all staff members that will clearly state the initial expectations of the church in their working together. Again, evaluation of relationship should encourage through regular, weekly staff meetings in building and developing staff relationship. Also, communicating the passion, vision, and the expectation of the church mission to the staff members goes a long way in building strong and an endurable relationship. 
Furthermore, organizing and attending staff retreat and seminars should not be left out in working, building and developing a relationship among staff members. Potential and actual conflicts must be dealt with without procrastination and not been judgmental in seeking to improve the relationship. In a nutshell, for staff relationships to be exemplary Christian relationships, staff members should follow the example of Jesus Christ toward the disciples. Jesus loved, taught, advised, counselled, comforted, and empowered his disciples. He also served as a model for them in humility, concern, faithfulness, patience, and openness. He called them his friends and considered them to be family, and these should be staff members' desire and attitudes in relationships.

\section{References}

Adetunji, Oluwaponmile Gideon. (2010). Leadership in Action: A Source in Church Administration for Students and Ministers. Ibadan: Baptist Press (Nigeria) Limited.

Adeniran, D. A. and Nihinlola, Emiola. (2011). Integrating Theology and Pastoral Ministry in Africa. (Nihinlola, Emiola. Ed.). Bangalore: Theological Book Trust.

Anderson, Leith. (1999). Leadership that Works: Hope and Direction for Church and Parachurch Leaders in Today's Complex World. Minneapolis, Minnesota: Bethany Publishers.

Anderson, Robert C. (1985). The Effective Pastor: A Practical Guide to the Ministry. Chicago: Moody Press.

Barlow, Jerry N. (2004). Interpersonal Relationship Skill for Ministers. (Bozeman, Jeanine Cannon and Smith, Argile. Ed.). Gretna, Louisiana: Pelican Publishing Company.

Beasley-Murray, Paul. (2005). Transform Your Church: 50 Very Practical Steps. England: InterVarsity Press.

Caldwell, William G. (2008). Church Administration Hand Book. (Powers, Bruce P. Ed.). Benin City: Religious Broadcasting Publishers.

Dale, Robert D. (2008). Church Administration Hand Book. (Powers, Bruce P. Ed.). Benin City: Religious Broadcasting Publishers.

Hayford, Jack. W. (2013). Leadership Handbook of Management and Administration. (Berkley, James. D. Ed.). Benin City: Beulahland Publications.

Hyles, Jack. (2013). Hyles' Church Manual. Indiana: Sword of the Lord Publishers.

Marshall, Tom. (1991). Understanding Leadership: Fresh Perspectives on the Essential of New Testament Leadership. England: Sovereign World Ltd.

Nash, Sylvia. (2013). Leadership Handbook of Management and Administration. (Berkley, James. D. Ed.). Benin City: Beulahland Publications.

Noyce, Gaylord. (1988). Pastoral Ethics: Professional Responsibilities of the Clergy. Nashville: Abingdon Press. Omotosho, J. Ola. (2009). She Real Model: Becoming a Model for God. Lagos: Latosh Publications.

Olson, David T. (2014). Discovering Your Leadership Style: The Power of Chemistry, Strategy and Spirituality. Downers Grove: InterVarsity Press.

Prime, Derek. (2009). Pastors and Teachers: The Calling and Work of Christ's Ministries. United Kingdom: Christian Books for Africa and Asia.

Spader, Dann and Mayes, Gary. (1991). Growing a Healthy Church-Complete with Study Guide. Chicago: Moody Press. 